\title{
MULTIPLE FACES OF THE NOSTALGIA CHANNEL IN RUSSIA
}

\author{
Ekaterina Kalinina \\ Södertörn University \\ Alfred Nobels allé 7 Flemingsberg \\ Stockholm, Sweden \\ ekaterina.kalinina@sh.se
}

\begin{abstract}
This article seeks to study Russian niche channel Nostalgia, which started broadcasting in 2004, and in particular, to explore the reasons behind founding this channel and the functions it fulfils, as envisioned by the channel's producers. The analysis is informed by semi-structured interviews with the channel's two main representatives - the producer and the first editor-in-chief, and content analysis of the programme, which was briefly examined for general attitude towards the Soviet past. At the same time this article aims at providing thorough insight into conceptualization of nostalgia relying upon the data from the interviews.
\end{abstract}

Keywords: Nostalgia, Niche television, Russia

\section{Nostalgia Channelin a Nutshell}

Non-fiction history programmes as well as vintage films and TV shows have become more present on the television screens during the last twenty years. ${ }^{1}$ It has been since 1985 when American viewers were able to enjoy old films and shows by subscribing to The Nostalgia Channel. Thanks to the internet channel GoodTV many can now watch American "good old classics" of the "time when television was good." However, channels broadcasting reruns of old news programmes, films and television shows in accordance to the old broadcasting nets are rather rare. That is why in this article I will shed some light on Russian niche channel Nostalgia.

My aim is to explore the reasons behind the creation of this channel, taking into consideration the expanding nature of nostalgia for the Soviet period in Russia. For this article my main sources were semi-structured interviews, which I carried out in 2013 with the producer Vladimir Ananich, the first editor-in-chief Michael Galich and author of one of the talk shows Elovaya Submarina Alexander Lipnitsky. I was particularly interested in how the producers came to the idea of launching such a channel; how they positioned the Nostalgia channel on the Russian television market; and how they argued for the choice of content. In this article I am also using a radio programme broadcasted on Radio Ekho Moskvy, where listeners and viewers were asking questions to Michael Galich and were commenting on the channel. ${ }^{2}$ At the same time I have studied the channel's programming and watched several documentaries and talk-

\footnotetext{
${ }^{1}$ Ann Gray and Erin Bell, History on Televion, Routledge, 2013.

2 Telekhronitel, Nostalgia po Staromu Televidineyu, Radio Ekho Moskvy, 6 July, 2008. Available online: http://www.echo.msk.ru/programs/ tv/524742-echol)
} 
shows with the aim of understanding the prevailing discourses on nostalgia and on the USSR. In this article I rely on Svetlana Boym's definition of nostalgia as 'a longing for a home that no longer exist or has never existed. Nostalgia is a sentiment of loss and displacement, but it is also a romance with one's own fantasy.' In the last section of this article I will provide a discussion on definition of nostalgia as given by the producers of the channel. ${ }^{3}$

Russian niche channel Nostalgia (producer Vladimir Ananich; first editor-in-chief Michael Galich) was first on air on 14 November, 2004. The channel broadcasts in Russia, Ukraine, Belarus, Kazakhstan, Moldova, Armenia, Georgia, Estonia, Latvia, Lithuania, Azerbaijan and the USA (i.e. countries with sizeable Russian minorities) and is available for subscription via cable networks and satellite TV (NTV Plus in Russia, Russian Mir in the world). The audience, according to the channel producers, is rather diverse and includes different generations of viewers. The older viewers, born in the 1950-1970s, watch Nostalgia channel because it reminds them about their youth and adventures; younger viewers are fascinated by the aesthetics of the past and curious about the history of their country. Vladimir Ananich nevertheless admitted that the channel is mainly popular among men aged from 40 to 60 who 'plunge into nostalgic journeys to their youth while drinking some vodka on a lonely Friday evening.'4

The Nostalgia channel is of particular interest to memory and media studies, as it was the first channel in the world to start imitating daily television broadcasts of the 1970s-1980s (and now increasingly even from the 1990s). This means that the channel's producers tried to reproduce daily schedules of a broadcasting day and attempted to schedule the original shows from morning till evening in the order, which was typical for the Soviet Tsentralnoe Televidenie ('Central Television'). Apart from vintage films, talk shows, and televised musicals, the Nostalgia broadcasts news programmes and even weather forecasts from the period. Besides broadcasting the programmes found in the State Archive of Radio and Television, the channel also shows documentaries and talk shows, where invited guests and anchors discuss events, which took place in the Soviet past. These shows and documentaries are specifically produced for the channel.

\section{Nostalgia Sells: Economic Reasons behind Reruns}

One should keep in mind that by the time the channel went on air for the first time, televised nostalgia for the Soviet period was already an established trend and Russian television was broadcasting many talk shows and documentaries, in which the Soviet past was revisited Namedni: Nasha Era 1961-1991 ('Yestervere: Our Era 19611991'), Stariy Televisor ('Old Television'), Staraya Kvartira ('Old Appartment'), Starie Pesni o Glavnom ('Old Songs about the Most Important Things') - all these programmes were broadcasted on central Russian television channels, such as Channel 1, Rossya, NTV in 1995-2002). Hence, it comes as little surprise that by 2003 the idea of launching a channel dedicated to Soviet films and reruns of Soviet era programmes and newsreels was, in the words of the producers, 'in the pipeline.' The channel simply hit the trend of growing commercialization of the recent past, where the symbolic universe of the Soviet Union acquired aesthetic and customer value; both in terms of visual and material culture. At that point of time Russian television had in this respect much to offer its viewers, but could not yet provide a whole day of non-stop content to evoke nostalgic sentiments. Many Soviet films were already available on DVD, but it was still difficult for an average viewer to find copies of vintage TV programmes or televised theatre plays on offer. That is why the start of the broadcasting of the archived Soviet media material became a huge step in popularising Soviet media across the vast territory of Russia and the former Soviet Union. Currently, Nostalgia is no longer the only channel entirely dedicated to reruns of Soviet television content: more recently the channel Retro was launched to tap the seemingly vast viewer demands. According to the producer of the Nostalgia channel, the Retro receives state funding and has much more resources to provide diverse and expensive content, compared with the privately owned Nostalgia. ${ }^{5}$

\footnotetext{
3 Svetlana Boym, The Future of Nostalgia, Basic Books, 2001, p. xiii.

Interview with Vladimir Ananich, 2013.

5 Interview with Vladimir Ananich, 2013.
} 


\section{6:00}

Programma A [Music and Song festivals in Sweden and Italy], 1990

07:00

Rozhdennie $v$ SSSR [Born in USSR, talk show]

08:05

Eti Neobiknovennie Muzikanti [These Unimaginable Musicians, musicale programme], 1977

09:10

Muzika I My [Music and Us, musical programme], 1987

10:20

Ptichiy Polet [Bird's flight, film], 1990

12:00

Do 16 I starshe [Untill 16 and older, youth programme], 1991

12:50

Nostalgiaya po Taskentu [Nostalgia for Tashkent, documentary], 2011

13:40

Dva Dnja v Nachale Dekabrja [Two days in the beginning of December, film], 1981

15:00

Vremya [news programme]

16:00

Rozhdennie $v$ SSSR [Born in USSR, talk-show]

Repetition from 25.11.2013

$17: 00$

Tvorcheskiy Vecher Kompozitora A. Pakmutovoy [Creative Evening of Composer A. Pakhmutova], 1975. Part 1

18:00

Elita Strani Sovietov [Elite of the Country of the Soviets]

18:50

Zolotaya Plastinka-2 [Golden Vinyl-2, film-concert ], 1983

19:30

Chelovek so Storoni [Man from the other side, televised theatre play, Part 1.], 1973

20:45

Spokoynoy Nochi, Malishi [ Babies Good night, children's evening programme]

21:00

Vremya [news programme]

22:00

Rozhdennie $v$ SSSR [Born in USSR, talk show, Live] 


\author{
23:00 \\ Tvorcheskiy Vecher Kompozitora A. Pakmutovoy [Creative Evening of Composer A. Pakhmutova], 1975. Part 2 \\ 00:00
}

Bilo Vremya [There was a Time, information-analytical programme], 2008

01:00

Kabachok 13 Stulyev [Pub 13 Chairs, entertaining programme], 1978.

02:15

Vecher Pamjati Vladimira Visotskogo [Evening in Memory of Vladimir Visotsky, concert], 1988

04:00

Proshalnie Gastroli [Goodbye Tour, film], 1992

05:10

Vechernii Melodii [Evening's Melodies, film-concert], 1985

Table 1: Programme, November 26, 2013

Source: http://www.nostalgiatv.ru/programs?day=2013-11-26\&dw=Tue.

According to the producers, the choice of content for rerunning depended on several factors: the condition and availability of the preserved programmes; whether the producers of the channel managed to secure copyrights for the chosen archive material; and the price of the content. Basically, even if the producers - out of interest or ideology would like to broadcast a specific content, it will ultimately be technological and economic mechanisms that determine the selection. Usually reruns of previously broadcast content are used for filling the timeslots, when channels are not supplying programmes, ${ }^{6}$ and this was what many channels in Russia were doing in the 1990 s - for obvious economic reasons.

Economically, rerun programming is a necessity for television broadcasters and cable channels (...). Airing episodes more than one time allows the industry to stretch its program investments. ${ }^{7}$

To make new programmes is much more expensive than to rerun old shows or films. Apparently, screening archive material was a very good investment: for a small amount of money, a channel could secure its broadcasting time by filling in time slots with content, which would more likely be appreciated by the viewers. But with time and with the growing demand for the archived television content, the prices went up, which made it more difficult for such small private channels to buy it. ${ }^{8}$ Reruns are attractive for channels, because 'media companies prefer to control economic risk by using actors, stories, or programmes that have a track record of past success. ${ }^{9}$ Considering that the producers by 2003 had taken notice of the popularity of the 'Soviet cultural heritage', their choice of content is understandable. According to scholarly research, audiences accept repeating broadcasts up to several times. ${ }^{10}$ There are several reasons for this. Burke wrote about 'a recurrent pleasure' of art, which occurs because 'the audience knows both the desires and resolution, and compensates for the loss of novelty.'11 The question is what motivates viewers to purchase subscriptions to such channels and spend days re-watching old news programmes and talk shows? Is it nostalgia?

\footnotetext{
6 John Weispfenning, 'Cultural Functions of Reruns: Time, Memory, and Television,' Journal of Communication, 53, 1, 2003.

7 Douglas, A. Ferguson and Susan Tyler Eastman, Broadcast/Cable/Web Programming: Strategies and Practices, Wadsworth/Thompson Learning, 2002 , p. 17.

${ }^{8}$ For instance Stream TV runs a Retro-TV channel that broadcasts films, documentaries, humoristic and musical programmes, TV-series and televised theatre plays from many countries.

9 John Weispfenning, 'Cultural Functions of Reruns: Time, Memory, and Television,' Journal of Communication, 53, 1, $2003,166$.

10 John Weispfenning, 'Cultural Functions of Reruns: Time, Memory, and Television,' Journal of Communication, 53, 1, $2003,166$.

11 Quoted in John Weispfenning, 'Cultural Functions of Reruns: Time, Memory, and Television,' ,Journal of Communication, 53, 1, $2003,167$.
} 


\section{Personal Nostalgia as One of Drivers behind the Creation of the Channel}

Media studies and especially research on advertising and marketing contributed significantly to the study of emotions produced by 'nostalgic content', and the consequences of the use of nostalgic sentiments in advertising. ${ }^{12}$ These investigations have shown that nostalgia preferences occur for a wide range of product categories that advertisements with a nostalgic theme are capable of producing nostalgic reflections and that nostalgic advertisements create more positive attitudes toward the ad, the product and the brand. ${ }^{13}$ These studies have revealed a great potential of nostalgia for developing of new products and brands due to the strong emotional connection customers might develop if a product reminds them about their personal past.

Communication scholars Diane Furno-Lamude and James Anderson (1992) found that nostalgia played an important role in explaining the attraction of rerun programmes. Their research has shown that viewers watched reruns

(...) Because it reminded them of their past, it reminded them of when they were younger and watched the program, they liked the program in the past, they wanted to look for different things, and (...) wanted to be reminded of the ending. ${ }^{\prime 14}$

The general producer of the channel, Vladimir Ananich, expressed his belief that the viewers were fascinated with the content of the channel because it reminded them about the time when they themselves were young: 'Nostalgia channel does not reminisce about the past; it is about recalling the time when you were young. But it is a channel created in such a way that makes it pleasant to remember how young we were. ${ }^{15}$ Ananich thought that watching old news programmes could remind people about important periods in life. Historical events shown on television function as important markers to activate their personal memories: 'Why rerun the Vremja programme? Because when one watches the news programme Vremja, one automatically identifies itself with that time. One starts counting: How old was I at that time? When this freak was speaking, I was listening to the radio station Golos Ameriki. ${ }^{16}$ From this perspective, nostalgia for one's youth and childhood, initiated by familiar media of the past, lead to a complex process of recalling personal life through the context of a whole epoch. However, some viewed nostalgia channel and people watching it as a symptom of some psychological illness.

\section{What Do We Speak about When We Speak about Nostalgia Reasons?}

In one of the radio programmes of Russian radio station Ekho Moskvy, Telekhranitel, ${ }^{17}$ the programme about the nature of television, people and events, which influenced the development of television as medium, the anchors talked about the value of old television with regard to new cultural tendencies and about the Nostalgia channel specifically. In

\footnotetext{
12 Susan L. Holak, Alexei V. Matveev and William J. Havlena, 'Nostalgia in post-socialist Russia: Exploring applications to advertising strategy,' Journal of Business Research, 61, 2, 2008, 172-178.

${ }_{13}$ See for example Morris B. Holbrook, 'Nostalgia proneness and consumer tastes' in John A. Howard, ed, Buyer behavior in marketing strategy, Englewood Cliffs, NJ: Prentice-Hall, 1994, pp. 348-364; Morris B. Holbrook and Robert M. Schindler, 'Echoes of the dear departed past: Some working progress on nostalgia,' Advances in Consumer Research, 18, 1991, 330-333; Morris B. Holbrook and Robert M. Schindler, 'Age, sex, and attitude toward the past as predictors of consumers' aesthetic tastes for cultural products,' Journal of Marketing Research, 31, 1994, 412-422; Morris B. Holbrook and Robert M. Schindler, 'Market segmentation based on age and attitude toward the past: Concepts, methods, and findings concerning nostalgic influences on customer tastes,' Journal of Business Research, 37, 1996, 27-39.

14 Quoted in John Weispfenning, 'Cultural Functions of Reruns: Time, Memory, and Television,' Journal of Communication, 53, 1, $2003,167$.

15 Interview with Vladimir Ananich, 2013.

${ }^{16}$ Interview with Vladimir Ananich, 2013.

17 This is a word game: telo (body) and tele (television) and khranitel (guard) and can be translated as 'guard of television.'
} 
the second half of the programme, listeners were invited to ask questions and share their opinions with the anchors. The dialogue below is representative of popular discourses on post-Soviet nostalgia and leads to the important discussion on the cultural role of the channel:

Listener: I listen to your programme with mute astonishment. Have you watched the movie Good Bye, Lenin!? It seems to me that this film is about you. There are many people for whom Brezhnev's speech, these ideological programmes, news programme Vremya is fun.

Anchor : Well, have you watched the channel Nostalgia?

Listener: No, I have not watched it (...). Perhaps, some of these programmes you show are historically or aesthetically valuable and important.

Anchor: Well, this is exactly what we are talking about.

Listener: But some things are exceptional. To make a channel, in which people are drowning in... people who have dropped out of modern life ... it's sick people, and you indulge them. ${ }^{18}$

Indeed, one could assume that nostalgia channel is a 'nostalgia pill' for those who want to escape the present and plunge into the past. Almost 24 hours broadcast of old programmes create an unprecedented feeling of being in a time capsule. One could start a day watching a sports programme from the 1960s, move on to the news about the achievements of the Soviet agriculture industry, continued by the weather report from 1985. Vladimir Ananich told a story of a group of people who travel to Ukraine and ended up in a hotel, where the Soviet ambience remained intact. The interior and the food all remained exactly the same as it was many years ago. When the TV set was switched on, it happened to be on the Nostalgia channel, which broadcasted one of Brezhnev's speeches. At that moment, it seemed to them that time has stopped and they were back to the period of stagnation. ${ }^{19}$ They realised that the Soviet Union had not ended with the collapse of the political regime. It actually still exists in people's daily lives.

This radio programme extracts also show that the listener defines the actions of looking back in time with nostalgic sentiments as some kind of incurable disease. It reveals that the discourse of nostalgia is rather prominent. I suggest briefly looking at history of the nostalgia concept to find out the traits, which might help us to understand what we are dealing with.

Nostalgia, as 'a painful yearning to return home' was first discussed in Johannes Hofer's dissertation in 1688, when he studied medical condition of Swiss mercenaries. ${ }^{20} \mathrm{He}$ described 'La Maladie du Pays' as a severe sickness, which could lead to a lethal outcome if not cured. The remedy suggested was a return home or a promise of it. In the 17th and the 18th centuries this physical and emotional upheaval was seen as a 'disorder of the imagination', while in the 19th century 'the word began to lose its purely medical meaning, in part because the rise of pathologic anatomy and bacteriology had simply made it less medically credible. ${ }^{21}$ In the $20^{\text {th }}$ century psychiatrists showed interest in nostalgia, and 'nostalgia became less a physical than a psychological condition', which went from being 'a curable medical illness to an incurable' condition of psyche. ${ }^{22}$ What made that transition possible was a shift in understanding nostalgia from the spatial to the temporal realms. Nostalgia was no longer seen as a desire to return to a place, but to a time of youth. ${ }^{23}$ 'Time, unlike space, cannot be returned to ever; time is irreversible. And nostalgia becomes the reaction to

\footnotetext{
${ }^{18}$ http://www.echo.msk.ru/programs/tv/524742-echol.

19 Interview with Vladimir Ananich, 2013.

20 Johannes Hofer, Medical dissertation on nostalgia (C.K. Anspach, Trans.), Bulletin of the History of Medicine, 2, 1934, (original work published 1688).

${ }^{21}$ Linda Hutcheon, 'Irony, Nostalgia, and the Postmodern. Methods for the Study of Literature as Cultural Memory,' Studies in Comparative Literature, 30, 1998, 194.

${ }^{22}$ Linda Hutcheon, 'Irony, Nostalgia, and the Postmodern. Methods for the Study of Literature as Cultural Memory,' Studies in Comparative Literature, 30, 1998, 194

${ }^{23}$ Linda Hutcheon, 'Irony, Nostalgia, and the Postmodern. Methods for the Study of Literature as Cultural Memory,' Studies in Comparative Literature, 30, 1998, 194
} 
that sad fact. ${ }^{24}$

Gradually, nostalgia has come to be viewed as more of a sociological phenomenon that helps individuals to adopt during major life transitions. Thanks to Fred Davis, who considered nostalgia as an 'adaptive mechanism' in turbulent times of transition, nostalgia was also seen as a productive attitude in more or less positive light. Thus, individuals going through dramatic changes in their lives would be more prone to nostalgic experiences. For example, people moving into a 'mid-life crisis', retirement, change of career path, or coping with divorce or personal losses might experience nostalgia.

According to Fred Davis, nostalgia could be viewed as a passive adaptation to cultural trauma. ${ }^{25}$ It is believed that the 'trauma of deindustrialisation' in the 1990s 'has brought about alcoholism, drug abuse, homelessness, and the feminization of poverty. ${ }^{26}$ It also caused mythologized image of the Soviet Union and nostalgia for the socialist past. Meanwhile, for those who had not been supporters of the socialist system, it took some time and 'distance to conceptualise their emotional trauma in a way that might validate the socialist past. ${ }^{27}$

Stephen Legg suggested a different approach to the theoretical and practical linkage between nostalgia and trauma:

While nostalgia denoted a positive attachment to a past real or imaginary home, trauma denoted the negative inability to deal effectively with a past event. While both conditions represent problematic engagements with the past, nostalgia often focuses on a time and place before or beyond a traumatic incident. ${ }^{28}$

Within this framework, both the destination for nostalgic longing and the traumatic event are located in the past and feed into contested memories activated in the present time. So if the traumatic conditions of the 1990s for many people exceed the shortcomings of their lives in the Soviet Union, the life in the Soviet Union becomes a destination for nostalgia.

Nevertheless, narrowing down explanation of both the viewers' motivation to watch this channel and the producers' intention to create it should not be just explained in the words of traumatic experiences, adaptation and understanding of nostalgia as an incurable psychological condition. Alexei Yurchak suggested another, more complex view of the post-Stalinist period between the mid-1950s and mid-1980s, which he called 'period of the late socialism.' He claims that the identities of people, who came of age during the 1970s and mid-1980s, were formed around shared experiences produced, but not necessarily defined by the structures and discourses of the authoritarian Soviet state. The complexity of this identity is according to Yurchak hidden in the fact that the majority of the population 'collectively participated in the production and reception of authoritative texts and rituals in the local contexts,' while at the same time they also were actively engaged in creating 'various identities and forms of living that were enabled by authoritative discourse, but not necessarily defined by it. ${ }^{29}$ Yurchak insisted on shifting from 'pro/anti dichotomy in relation to authoritative discourse,' as the performative acts adopted by many Soviet citizens did not fit this binary oppositional structure. He called for the importance of the analysis of the Soviet system in all its complexity and with inherited paradoxes in order to explain today's phenomenon of post-Soviet nostalgia. He wrote that people's everyday life "was not necessarily equivalent to "the state" or "ideology"; indeed, living socialism to them often meant something quite different from the official interpretations provided by state rhetoric. ${ }^{30}$ Hence part of post-Soviet nostalgia,

\footnotetext{
24 Linda Hutcheon, 'Irony, Nostalgia, and the Postmodern. Methods for the Study of Literature as Cultural Memory,' Studies in Comparative Literature, 30, 1998, 194.

25 Fred Davis, Yearning for yesterday: a sociology of nostalgia, Free Press, 1979.

${ }_{26}$ Maria Todorova and Zsuzsa Gille, eds, Postcommunist Nostalgia, Berghahn Books, 2010, p. 5.

27 Maria Todorova and Zsuzsa Gille, eds, Postcommunist Nostalgia, Berghahn Books, 2010, p. 36.

28 Stephen Legg, 'Memory and Nostalgia,' Cultural Geographies, 11, 2004, 103.

29 Yurchak Alexei, Everything Was Forever Until It Was No More. The Last Soviet Generation. Princeton NJ: Princeton University press, 2006, p. 32.

${ }_{30}$ Yurchak Alexei, Everything Was Forever Until It Was No More. The Last Soviet Generation. Princeton NJ: Princeton University press, 2006, p. 8.
} 
Is the longing for the very real humane values, ethics, friendship, and creative possibilities that the reality of socialism afforded - often in spite of the state's proclaimed goals - and that were as irreducibly part of the everyday life of socialism as were the feelings of dullness and alienation. ${ }^{31}$

Coming back to the comments about 'sick people' provided by the listener in the radio programme, I want to point out that understanding of post-Soviet nostalgia as a psychological illness was a rather widespread phenomenon, which I described in detail elsewhere. ${ }^{32}$ In contrast to this opinion, the words of Anatoly Lysenko, the director-general of Public Television broadcasting in Russia (at the point when the programme was on air in 2008), resonate well with Yurchak's explanation of the causes for nostalgia: 'For people at a certain age, it [nostalgia] is always a return into youth, and despite it all, youth is always youth and it is pleasant to remember it. ${ }^{33}$ If we are to believe the producers, their own personal nostalgia for youth, curiosity, interest in the historical period, when they were young, were among the reasons for the creation of such a channel.

\section{Functions of the Channel: Creation of Time Continum and Link between Generations}

In the interview Michael Galich stressed that one of the main reasons for creating the channel was to provide an understanding of a certain continuation of historical processes: 'The link between times was broken, so we wanted to restore this continuity. In our minds everything was disconnected. There is sovok, ${ }^{34}$ then perestroika, and now there is another global stagnation. When we started the channel, there was a very distinct feeling of a broken time continuum. We lived in another country, another society, and the attempt to understand the present, to find our roots, to understand that we have the same background played an important role. ${ }^{\prime 35}$

This function of providing a coherent narrative of a Soviet past is mainly fulfilled by numerous documentaries and talk shows produced by the channels. Alexander Lipnitsky, author of music programmes about Russian rock Elovaya Submarina, said that function of his programme was to preserve and pass on knowledge about creative individuals, active during the late socialist period, and about the unique culture of that time. ${ }^{36}$ These talk-shows also fulfilled an important function in the process of remembering: they carry on discussions that allow for different voices and opinions to be heard - they have invited representatives of different political camps to express oppositional views and therefore to show the complexity of the period.

Next to the recordings of the party congresses, the channel shows concerts of many Western music bands, thus mixing the content that was available on the Soviet television during the period of late socialism with one that was not accessible through legal channels. In this sense, the channel presents a version of television many people, who lived in that period, wanted to watch. It became an alternative version of the Soviet television, where favourite films produced in the Soviet Union were followed first by the concerts of the bands one could only listen to by smuggling vinyl or making home recordings, followed by serious talk shows, where witnesses of the past events discussed different aspects of life in the Soviet Union.

Watch the Nostalgia Channel programme Bilo Vremja here.

Watch the talk show Rozhdennie v SSSR here.

\footnotetext{
31 Yurchak Alexei, Everything Was Forever Until It Was No More. The Last Soviet Generation. Princeton NJ: Princeton University press, 2006, p. 8.

32 Ekaterina Kalinina, 2014, Mediation of post-soviet nostalgia, doctoral dissertation (forthcoming)

${ }^{33}$ Telekhronitel, 6 July, 2008

34 Untranslatable expression describing Soviet mentality and way of life; literary translation is 'a scoop.'

35 Interview with Michael Galich, 2013.

36 Interview with Alexander Lipnitsky, 2013.
} 
At the same time the channel creates a link between larger groups of individuals by broadcasting not only in Russia, but also across former Soviet republics and the USA, thus uniting people that were disconnected by the political events of the early 1990s. Individual memories of these people become supplied by social points of reference, which the channel produces in the form of reruns. It allows people to learn about themselves and share this knowledge with younger generations. The reruns become 'a form of visual record that locates collective memory in a fixed form, although not in a fixed space. ${ }^{37}$ Hence, the channel has a role of cross-generational information, collective memory and social continuity.

\section{Restorative and Reflexive Nostalgia}

Svetlana Boym in The Future of Nostalgia divided nostalgia into two types: the restorative and the reflective.

'Restorative nostalgia stresses nostos and attempts a trans-historical reconstruction of the lost home. Reflective nostalgia thrives in algia, the longing itself, and delays the homecoming - wistfully, ironically, desperately. ${ }^{38}$

If restorative nostalgia thinks of itself not as nostalgia but as tradition, and protects a kind of absolute truth, reflective nostalgia calls truths and traditions into doubt, leaving space for contradictions.

This dual nature of nostalgia is important to remember when calling something nostalgic. Looking back into the past with the aim of revisiting does not necessarily involve a desire to return the former state of affairs. It might actually mean a start of an important process of recollection and re-working not only the past traumas, but also understanding of what occurs in the present and to conceptualise one's position among others. In other words, reflective nostalgia referring to the past contributes to the construction of one's cultural or/and collective identities in the present.

When it came to defining what nostalgia is and whether one can consider the channel 'nostalgic,' the conversation revealed the difficulty of coming to a common understanding of the term. The producers referred to this duality of nostalgia and they made rather clear distinctions between nostalgia on their channel and nostalgia elsewhere on television. According to Annanich, one could be nostalgic for the time of youth, and this type of nostalgia the channel is feeding to. At the same time the producers stressed that despite the broadcasting of the Soviet shows, the channel, is not calling for the restoration of the previous ideology or political order:

Ananich: Compared to your official channels (federal channels), Nostalgia is a super-dissident channel.

Galich: If you switch on the programme Vremja, you will see that we show the presence; that we often show what happens in future.

Ananich: Nostalgia is not a channel that repeats that old ideology. The way it is programmed allows for the presence of dissidents. Do you think that we could see how the Rolling Stones or the Doors looked like back then? Now it is possible not only to hear them, but also to watch them. And during that time, dissidents were not present on television. ${ }^{39}$

The producers considered talk shows on the channel to be devoid of any nostalgic sentiments. When it came to comparing their own work with other similar attempts, they clearly drew the line between "us" and "them". They believed that comparing to programmes like Staraya Kvartira ('Old Appartment', broadcasted in the second half of the

\footnotetext{
37 John Weispfenning, 'Cultural Functions of Reruns: Time, Memory, and Television,' Journal of Communication, 53, 1, 2003, 170.

38 Svetlana Boym, The Future of Nostalgia, Basic Books, 2001, p. xviii.

39 Nostalgia po Staromu Televideniju, Radio Echo Moskvy, 6 June, 2008.
} 
1990s on the channel Rossiya), which in their opinion was 'absolutely nostalgic', talk shows of the Nostalgia channel do not propagate life in the Soviet Union as a positive experience, but try to understand the course of events and be critical towards the past..$^{40}$ Paradoxically, the show Staraya Kvartira, which was broadcast in the middle of the 1990s on Russian television, was a talk show where the anchors together with the public were trying to come to terms with the past through the process of collective remembering and hardly described life in the Soviet Union as a positive experience. It is true that certain aspects of life in the Soviet times were reviewed in Staraya Kvartira with positive, often ironic attitude, but it was done to show the complexity of life. The same could be said about the Nostalgia channel. The producers amplified the differences between Staraya Kvartira and the channel's talk shows, despite of the obvious similarities between the talks shows and their attitudes towards the Soviet past.

Defining what nostalgia is became even more difficult, when Michael Galich said that nostalgia is any look back to the past. He believed that switching on the Nostalgia channel to watch an old film is already and 'act of nostalgia', 'nostalgia in its purest form. ${ }^{31}$ However, when someone produces a new documentary or a talk-show where the past is discussed, then it is not nostalgia any longer; it is an analysis of the past. Thus, he believed, nostalgia is not a reflexive act of thinking, but an emotional urge to go back to the past. In this light he saw the Nostalgia channel as a remedy for those who are nostalgic; in other words, those who harbour utopian dreams about the past and wish for its return. According to him the channel did not have any content, which could be called nostalgic, but they were the users, who experienced nostalgia - they were the ones switching on the TV sets after all. Galich said that restorative nostalgia, which is back on the agenda 'is not correct, it is ideologised and mythologised. Today our role has actually changed; we destroy the myths that are being built. We show how it was in reality. ${ }^{42}$

Both Valdimir Ananich and Michael Glaich saw nostalgia on other channels of Russian television and in other programmes similar to the productions on the Nostalgia channel. In this case, they often understood nostalgia as a restoration of the Soviet political rhetoric and discourses. By contrast, they saw their own work as educational and journalistic, comparing to 'all other' programmes, which were produced 'in order to call for nostalgic emotions'. Their work thus became an important marker of their identity and the identity of the channel among other communication networks in Russia. Hence, after watching the programmes on the channel one would become more knowledgeable about the past and would give up dreams of its restoration.

The producers, similar to the listener in the radio programme, saw those who experienced restorative nostalgia, as 'sick' people, unable to cope with the present day reality, thus confirming to the understanding of nostalgia as a psychological illness; incapability to cope with everyday life. They believed that there were masses out there, who consumed media content without critical reflection, passive audience groups that lack agency.

The radio listener divided television audiences in two contrasting groups: 'we' who are able to select and analyse the content shown; and 'they' - the 'others' - who watch television without understanding what they are watching and therefore easily persuaded. These two groups have very different relations with the past. One group is reflective and takes a critical approach both to the past events and to how they are represented in the media. For this group of viewers, nostalgia is a longing for the youth of the past, not for the Soviet state. Another group is prone to believe to the myths and wishes for restoration.

The content producers also believe in the existence of these two types of audiences, and thus see their channel as having educational objective, and place themselves in this category. They believe that they approach the past critically and creatively and regard their audiences as similar to them, i.e. consuming contents, simultaneously, seriously and ironically. The other group of viewers is believed to be passive consumers, nostalgic for the myths of the powerful Soviet empire. These people might wish for the restoration of the previous military power and strong empire. They consume media and creative content without much reflection and are, as a result, being looked down upon. This group is usually also associated with the electorate of the ruling political forces. They are believed to support the

\footnotetext{
40 Interview with Valdimir Ananich and Michael Galich, 2013.

41 Interview with Michael Galich, 2013.

42 Interview with Michael Galich, 2013
} 
authoritarian direction of the contemporary political order. The producers pointed out to their colleagues, who, in their opinion, gratified the demands of these 'sick' audiences.

In order to test whether these speculation done by the producers is grounded in social reality one has to do a profound audience research, which is not possible within the limited frames of this article. What can be said at this stage is that the producers were not always informed about the other programmes they referred to. Sometimes they dissembled certain facts and details about what others were doing to overemphasize their own significance.

\section{Conclusion}

As this study shows, obvious economic incentives were among the reasons behind the creation of the Nostalgia channel. Rerunning archive television material was a non-expensive way of filling in programming time during the early days of channel. Providing an interest about the Soviet past was booming in the first half of the 2000s, emergence of the channel seemed to be a logical continuation of the trend, including commercialisation of nostalgic sentiments. However, the founders of the channel did not make any substantial profit due to the increased costs of the archival television footage and the economic model based on subscription could not function as a sustainable long time strategy. Another reason behind the founding of the channel was a personal curiosity and nostalgia for the youth of the makers of this channel. Among the functions the channel fulfilled there is an obvious cultural-educational function. The channel gave access to archive materials and aimed at providing meaningful narratives about the Soviet past.

When it comes to the definition of nostalgia, the picture becomes more blurred. The producers said that nostalgia could be any form of looking back to the past, any emotional involvement with the past. At the same time, they made a difference between nostalgia as an emotional longing for one's personal past, which irreversibly passed and nostalgia as a conscious attempt to restore previous political order. They have admitted that they themselves might experience nostalgia for their own youth, but their own relation to the past is rooted in critical analysis. They utilized a binary between "us" and "the others" while "the others", in their opinion, plunged into emotional nostalgia, portraying the past as a positive myth and longing to restore the previous political order.

\section{Bi ograph y :}

Ekaterina Kalinina is a PhD candidate at the Department of Media and communication, Södertörn University, Sweden. She wrote her doctoral dissertation about the phenomenon of post-Soviet nostalgia in contemporary Russia. Among her research interests are questions of identity, nationalism, fashion, cultural memory, nostalgia. 